\title{
THE SOCIODEMOGRAPHIC CHARACTERISTICS, CLINICAL PROFILE AND TREATMENT RECORDS OF ANOGENITAL WARTS IN EASTERN UTTAR PRADESH- A RETROSPECTIVE EVALUATION FROM TREATMENT RECORDS AT A TERTIARY CENTRE
}

\author{
Harleen Chhachhi', Anil Kumar Gupta ${ }^{2}$, Santosh Kumar Singh ${ }^{3}$, Rakesh Kumar Patel ${ }^{4}$, Pawan Kumar Patel ${ }^{5}$, \\ Raj Kumar 6 , Avnish Kumar ${ }^{7}$ \\ ${ }^{13}$ rd Year Junior Resident, Department of Dermatology, BRD Medical College, Gorakhpur. \\ ${ }^{2}$ Associate Professor, Department of Dermatology, BRD Medical College, Gorakhpur. \\ ${ }^{3}$ Associate Professor, Department of Dermatology, BRD Medical College, Gorakhpur. \\ ${ }^{4} 3^{\text {rd }}$ Year Junior Resident, Department of Dermatology, BRD Medical College, Gorakhpur. \\ ${ }_{53}{ }^{\text {rd }}$ Year Junior Resident, Department of Dermatology, BRD Medical College, Gorakhpur. \\ ${ }^{6} 3^{\text {rd }}$ Year Junior Resident, Department of Dermatology, BRD Medical College, Gorakhpur. \\ ${ }^{7}$ Senior Resident, Department of Paediatrics, BRD Medical College, Gorakhpur.
}

\section{ABSTRACT}

\section{BACKGROUND}

Human Papillomavirus (HPV) infection is one of the most prevalent Sexually Transmitted Disease (STD). Up to the researchers' knowledge, no study concerning the genital warts in Eastern Uttar Pradesh was published, which was a motivation to study this problem.

\section{AIMS}

A retrospective study in the referral centre for Sexually Transmitted Infections (STIs) in Eastern UP to describe the sociodemographic characteristics, clinical profile and treatment of anogenital warts in Eastern Uttar Pradesh.

\section{DESIGN}

Retrospective cross-sectional study.

\section{MATERIAL AND METHODS}

All patients with the diagnosis of anogenital warts between the years 2009-2013 confirmed at the tertiary centre were examined retrospectively. Age, sex, sexual orientation, month of diagnosis, duration of infection, site of warts, treatment given and duration of treatment were noted. Other STD found in these patients was recorded. The outcomes of the treatment modalities for the treatment of anogenital warts during the study period were compared.

\section{STATISTICAL ANALYSIS \\ Fisher test to compare outcomes of 2 treatment modalities. \\ RESULTS}

Maximum burden of the disease was in the patients of age group 25-35 years with 193/640 (30.2\%) patients in the category. Majority (67.5\%) of the patients were male, majority (58.6\%) belonged to rural areas; $87.2 \%$ had a positive history of contact; $66 / 548(12.04 \%)$ had homosexual relationship; 30.5\% patients accepted that their mode of acquisition was through contact with commercial sex workers. Mean duration of warts before approach for treatment was 2-4 months. Majority of male patients had penile warts $(51.4 \%)$ and majority of female patients had warts on the post fourchette $(41.3 \%) ; 83.8 \%$ patients accepted the fact of never adapting the means of safe sexual practices; $59.5 \%$ patients had more than 1 sexual partners; $20 \%$ of patients had records of other STD's as well, majority being HIV and herpes. The treatment of warts continues to be problematic. In my study podophyllin (20\%) proved to be a much better treatment modality than imiquimod (5\%) for the treatment of genital warts.

\section{CONCLUSION}

From treatment records prevalence of anogenital warts seem to be much lower than stated in the national records. The difference noted may be on account of study methodology of treatment records rather than active surveillance of patients. Statistically significant results with podophyllin as a better treatment option were seen.

\section{KEYWORDS}

Anogenital Warts, Socio-demographic Characteristics, Eastern Uttar Pradesh, Podophyllin, Imiquimod.

HOW TO CITE THIS ARTICLE: Chhachhi H, Gupta AK, Singh SK, et al. The sociodemographic characteristics, clinical profile and treatment records of anogenital warts in Eastern Uttar Pradesh- A retrospective evaluation from treatment records at a tertiary centre. J. Evolution Med. Dent. Sci. 2016;5(12):491-495, DOI: 10.14260/jemds/2016/112

Financial or Other, Competing Interest: None.

Submission 22-12-2015, Peer Review 21-01-2016,

Acceptance 27-01-2016, Published 09-02-2016.

Corresponding Author:

Dr. Harleen Chhachhi,

26, Paras Ram Nagar,

West Shivaji Nagar, (Near Dr. Maria School),

Shahganj, Agra-282010.

E-mail: drharleenchhachhi@gmail.com

DOI: $10.14260 /$ jemds/2016/112

\section{INTRODUCTION}

Anogenital Human Papillomavirus (HPV) is the most frequent sexually transmitted viral infection in the world, which can result in malignant cancers or benign skin and mucosal tumors including Anogenital Warts (AGWs).[1] AGWs are categorized as a clinical anogenital HPV infection, because they manifest as visible lesions, namely as single or multiple papules on the vulva, perineum, perianal area, vagina, cervix, penis, anus, scrotum and urethra.[1] 
Clinical symptoms may include pruritus, burning, vaginal discharge and bleeding.[2] Four distinct subtypes of AGWs have been described: condylomata acuminata (Pointed warts), flat/macular lesions, papular and keratotic lesions.[1] The first two sub-types are mainly found on moist, non-keratinized epithelia, while the latter two usually present on keratinized epidermis.[1] AGWs are also often referred to as genital warts, condylomata acuminata or genital verruca, although strictly speaking the first two terms are subsets of the anogenital category.

HPV 6 and 11 account for the majority of AGW cases.[1,3-5] AGWs are highly infectious; approximately $65 \%$ of individuals with an infected partner develop AGWs within 3 weeks and 8 months. [6] In rare cases, AGWs can be associated with malignant lesions, namely Buschke-Lowenstein tumors.[5] Recent prospective studies reported that the median time between infection with HPV types 6 or 11 and the development of AGWs was 11 to 12 months among males.[7,8] and 5 to 6 months among young females. ${ }^{[9]}$ Although, there are no severe health complications or mortality associated with AGWs, there are significant psychosocial issues which often ensue. $[10,11]$

Treatment options include patient-applied (Homebased) chemical treatments (Podofilox, imiquimod), physician-applied (Office-based) chemical treatments (Podophyllin, trichloroacetic acid, interferon, green tea extract.[12]) and ablative treatments (Cryotherapy, surgical removal, laser treatment).[13-16] The main limitation of current therapies is the high recurrence rate after initial remission. $[15,17,18]$ The quadrivalent HPV vaccine demonstrated high efficacy in preventing the onset of HPV 6/11-related AGWs in both males.[19] and females.[20]

Although, AGWs rank among the most frequent Sexually Transmitted Diseases (STD).[21,22] the epidemiology and of AGWs is not well characterized. In order to implement measures of prophylaxis, to increase awareness among people for the anogenital warts it is important to assess the extent of the infection in the area and various socio-demographic variables affecting the spreadability of disease in the concerned area. There is relative paucity of data in Eastern UP, which necessitated this study.

\section{METHODS}

All patients who had the diagnosis of anogenital warts in 5 years period, i.e. from 2009-2013 confirmed at the tertiary centre in Eastern UP by clinical or histopathological methods had their medical records examined retrospectively. Detailed medical records of patients with sexually transmitted diseases including anogenital warts are maintained at the separate STI clinic (Sexually Transmitted Infection Clinic) of the tertiary referral centres. The records had a mention of the age, sex, locality of infected patients and phone numbers (For the provision of contact tracing of the patients), educational level, employment status, month of diagnosis, sexual orientation, number of sex partners a patient is indulged with, duration of infection, site of warts, type of warts, treatment given and duration of treatment given to the patients which were noted. Other sexually transmitted diseases found in these patients were also noted.

We also attempted to interview every patient by telephone to find out if they had any clinical recurrences for which treatment was sought elsewhere.
Statistical analysis was done to compare the outcomes of the main modalities of treatment for anogenital warts during the study period.

\section{RESULTS}

A total of 640 patients were reported with the diagnosis of anogenital warts at the STI (Sexually Transmitted Infections) Clinic in the referral centre of the Eastern UP area.

Sociodemographic parameters of patients-

\begin{tabular}{|c|c|}
\hline AGE (IN YEARS) & $\begin{array}{c}\text { NUMBER OF PATIENTS } \\
(\mathbf{n = 6 4 0 )}\end{array}$ \\
\hline $13-25$ YRS & 112 \\
\hline $25-35$ YRS & 193 \\
\hline $35-45$ YRS & 168 \\
\hline $45-55$ YRS & 97 \\
\hline 55-65 YRS & 70 \\
\hline \multicolumn{2}{|c|}{ Table 1: age distribution of patients } \\
\hline
\end{tabular}

\begin{tabular}{|c|c|}
\hline Males & Females \\
\hline $432(67.5 \%)$ & $208(32.5 \%)$ \\
\hline \multicolumn{2}{|c|}{ Table 2: Sex distribution of patients } \\
\hline
\end{tabular}

\begin{tabular}{|c|c|}
\hline Rural Area & Urban Area \\
\hline 375 patients (58.6\%) & 265 patients (41.4\%) \\
\hline \multicolumn{2}{|c|}{ Table 3: Locality (Rural/Urban) of patients } \\
\hline
\end{tabular}

\begin{tabular}{|c|c|}
\hline Educational Level & No. of Patients \\
\hline Illiterate & 206 patients $(32.2 \%)$ \\
\hline$<10^{\text {th }}$ std. & 97 patients $(15.15 \%)$ \\
\hline $10^{\text {th }}-12^{\text {th }}$ std. & 100 patients $(15.6 \%)$ \\
\hline Graduate & 173 patients $(27.03 \%)$ \\
\hline Post Graduate & 64 patients $(10.0 \%)$ \\
\hline \multicolumn{2}{|c|}{ Table 4: Educational status of patients } \\
\hline
\end{tabular}

\begin{tabular}{|c|c|}
\hline Married & Unmarried \\
\hline 410 patients (64\%) & 230 patients (36\%) \\
\hline \multicolumn{2}{|c|}{ Table 5: Marital status of Patients } \\
\hline
\end{tabular}

\begin{tabular}{|c|c|}
\hline Employed & Unemployed \\
\hline 444 patients (69.4\%) & 196 patients (30.6\%) \\
\hline \multicolumn{2}{|c|}{ Table 6: Employment status of patients } \\
\hline
\end{tabular}

\begin{tabular}{|c|c|}
\hline Profession & $\begin{array}{c}\text { No. of patients } \\
(\mathbf{n}=\mathbf{4 4 4 )}\end{array}$ \\
\hline Labourers & 178 patients $(40.09 \%)$ \\
\hline Truck drivers & 52 patients $(11.7 \%)$ \\
\hline Defence & 23 patients $(5.2 \%)$ \\
\hline White collars & 114 patients $(25.67 \%)$ \\
\hline Other & 77 patients $(17.3 \%)$ \\
\hline Table 7: Profession of employed patients
\end{tabular}

\begin{tabular}{|c|c|}
\hline Sexually active & Sexually inactive \\
\hline 548 patients (85.6\%) & 92 patients (14.4\%) \\
\hline \multicolumn{2}{|c|}{ Table 8: Sexual activity of patients } \\
\hline
\end{tabular}

\begin{tabular}{|c|c|}
\hline Heterosexual & Homosexual \\
\hline 482 patients (87.9\%) & 66 patients $(12.1 \%)$ \\
\hline \multicolumn{2}{|c|}{ Table 9: Sexual orientation of sexually } \\
active patients ( $\mathbf{n = 5 4 8 )}$
\end{tabular}




\begin{tabular}{|c|c|}
\hline Positive & Negative \\
\hline 478 patients $(87.2 \%)$ & 70 patients $(12.8 \%)$ \\
\hline $\begin{array}{r}\text { Table 10: History of contact in sexually } \\
\text { active patients }(\boldsymbol{n}=\mathbf{5 4 8})\end{array}$ \\
\hline
\end{tabular}

\begin{tabular}{|c|c|}
\hline Commercial Sex Workers & Others \\
\hline 146 patients (30.5\%) & 332 patients (69.5\%) \\
\hline $\begin{array}{c}\text { Table 11: Source of exposure in patients with positive } \\
\text { contact history (n=478) }\end{array}$ \\
\hline
\end{tabular}

\begin{tabular}{|c|c|}
\hline $\begin{array}{c}\text { Duration of Illness (In } \\
\text { months) }\end{array}$ & $\begin{array}{c}\text { No. of Patients } \\
\text { (n=640) }\end{array}$ \\
\hline$<2$ months & 178 patients $(27.8 \%)$ \\
\hline $2-4$ months & 284 patients $(44.4 \%)$ \\
\hline $4-6$ months & 100 patients $(15.6 \%)$ \\
\hline 6-7 months & 78 patients $(12.2 \%)$ \\
\hline Table 12: Duration of illness in months \\
\hline
\end{tabular}

\begin{tabular}{|c|c|}
\hline Area Involved & $\begin{array}{c}\text { Number of Male } \\
\text { Patients } \\
(\mathbf{n = 4 3 2})\end{array}$ \\
\hline $\begin{array}{c}\text { Penis (Incl glans, prepuce, penile } \\
\text { shaft) }\end{array}$ & $222(51.4 \%)$ \\
\hline Scrotum & $62(14.4 \%)$ \\
\hline Perineum & $31(7.2 \%)$ \\
\hline Perianal & $35(8.1 \%)$ \\
\hline Mixed & $82(19 \%)$ \\
\hline Table 13: Genital area involved in male patients \\
\hline
\end{tabular}

\begin{tabular}{|c|c|}
\hline Area Involved & $\begin{array}{c}\text { Number of Patients } \\
(n=208)\end{array}$ \\
\hline Labia & $42(20.2 \%)$ \\
\hline Posterior fourchette & $86(41.3 \%)$ \\
\hline Perineum & $35(16.8 \%)$ \\
\hline Perianal & $15(7.2 \%)$ \\
\hline Mixed & $30(14.4 \%)$ \\
\hline
\end{tabular}

\begin{tabular}{|c|c|}
\hline Type of Warts & $\begin{array}{c}\text { Number of Patients } \\
\text { (n=640) }\end{array}$ \\
\hline Plane warts & $72(11.3 \%)$ \\
\hline Filiform warts & $196(30.6 \%)$ \\
\hline Accuminate warts & $266(41.5 \%)$ \\
\hline Verrucal warts & $106(16.6 \%)$ \\
\hline \multicolumn{2}{|c|}{ Table 15: Types of anogenital warts } \\
\hline
\end{tabular}

\begin{tabular}{|c|c|}
\hline Patients using condoms & Patients not using condoms \\
\hline 89 patients $(16.2 \%)$ & $459(83.8 \%)$ \\
\hline Table 16: Protective barrier usage in sexually active \\
patients- $(n=548)$
\end{tabular}

\begin{tabular}{|c|c|}
\hline 1 partner & >1 partner \\
\hline 222 patients $(40.5 \%)$ & 326 patients $(59.5 \%)$ \\
\hline \multicolumn{2}{|c|}{ Table 17: Number of sexual partners } \\
of patients $(\mathbf{n}=\mathbf{5 4 8 )}$
\end{tabular}

\begin{tabular}{|c|c|}
\hline Other STD's Present & Absent \\
\hline $110(20.1 \%$ patients $)$ & $438(79.9 \%$ patients $)$ \\
\hline Table 18: History of other STD in sexually active patients \\
$(\mathbf{n = 5 4 8 )}$
\end{tabular}

\begin{tabular}{|c|c|}
\hline Other STD Present & $\begin{array}{c}\text { Number of Patients } \\
(\mathbf{n = 1 1 0})\end{array}$ \\
\hline HIV & 42 \\
\hline Herpes genitalis & 32 \\
\hline Trichomonas & 18 \\
\hline Hepatitis B & 09 \\
\hline Scabies & 09 \\
\hline \multicolumn{2}{|c|}{ Table 19: Other STD records of patients } \\
\hline
\end{tabular}

Maximum burden of the disease was in the patients of age group 25-35 years with 193/640 (30.2\%) patients in the category followed by those in age group 35-45 yrs. with $168 / 640$ (26.3\%) patients (Table 1). Majority (67.5\%) of the patients were male (Table 2), majority (58.6\%) belonged to rural areas (Table 3); $47.3 \%$ patients were either uneducated or had a low educational level (Table 4). Marital status of patients is shown in Table 5. Of the employed patients, $40 \%$ were labourers (Tables 6, 7). Sexual activity and sexual orientation of patients is shown in Tables 8, 9; 478/548 (74.7\%) accepted on the fact of their positive history of contact (Table 10); 29.8\% patients accepted that their mode of acquisition was through contact with commercial sex workers (Table 11). Mean duration of warts before approach for treatment was 2-4 months (Table 12). Majority of male patients had penile warts $(51.4 \%)$ and majority of female patients had warts on the post fourchette (41.3\%), the site of maximum coital friction (Tables 13,14). Most of the patients recorded from the area had condyloma accuminata (41.5\%) (Table 15); 83.8\% patients accepted the fact of never adapting the means of safe sexual practices (Table 16); 59.5\% patients had more than 1 sexual partners (Table 17); $20 \%$ of patients had records of other STD's as well, majority being HIV and herpes (Tables 18, 19).

The prevalence as from the treatment records came out to be lower than the reported nationwide prevalence. The difference noted may be on account of study methodology of treatment records rather than routine genital examination and active surveillance of patients, which would be a better estimate of the prevalence of disease in the area. The difference especially of lower prevalence of anogenital warts in the female patients from the records could be accounted by the fact of hidden and asymptomatic carriage of infection in the cervical or anal mucosa without coming to patient's knowledge. This could only come into light by routine genital examination of suspected patients through routine cervical smear. Further reluctance and shame on the part of female patients could also defer them from coming to the treatment centres.

The illiteracy and unprotected sexual intercourse of majority of patients brought into light the lack of awareness and knowledge among the people about HPV and genital warts. This was especially seen with adolescent age group where $>60 \%$ denied any knowledge of HPV before acquiring the infection. There is a great need to fill this knowledge gap, especially in adolescent population to bring down prevalence of disease in the area.

\section{Treatment}

One of the following treatment modalities was given to the patients: 
1. $5 \%$ Imiquimod cream was applied to the lesions and then advised to apply it every alternate day by themselves for duration of 6 weeks.

2. Topical $20 \%$ Podophyllin lotion was applied to the lesion once weekly under supervision and the same treatment was repeated for 6 weeks.

\begin{tabular}{|c|c|}
\hline Podophyllin 20\% & Imiquimod 5\% \\
\hline 352 patients & 288 patients \\
\hline \multicolumn{2}{|c|}{ Table 20: Treatment modality used } \\
\hline
\end{tabular}

\begin{tabular}{|c|c|}
\hline Treatment & Completely Cured Patients \\
\hline Podophyllin & $238 / 352(67.6 \%)$ patients \\
\hline Imiquimod & $93 / 288(32.3 \%)$ patients \\
\hline Table 21: Patients completely healed with the treatment \\
\hline
\end{tabular}

\begin{tabular}{|c|c|c|c|}
\hline & 2wks & 4wks & 6wks \\
\hline Podophyllin & 39 patients & 90 patients & 109 patients \\
\hline Imiquimod & 21 patients & 30 patients & 42 patients \\
\hline Table 22: Time period for complete clearance of warts in \\
the respective treatment groups
\end{tabular}

\begin{tabular}{|c|c|}
\hline Podophyllin & Imiquimod \\
\hline 92 patients (38.6\%) & 28 patients (30.1\%) \\
\hline \multicolumn{2}{|c|}{ Table 23: Recurrence in patients with complete } \\
clearance of anogenital warts
\end{tabular}

\begin{tabular}{|c|c|}
\hline TREATMENT GIVEN & $\begin{array}{c}\text { PATIENTS WITH } \\
\text { INCOMPLETE CLEARANCE } \\
\text { (n=26) }\end{array}$ \\
\hline $\begin{array}{c}\text { RADIOFREQUENCY } \\
\text { ABLATION }\end{array}$ & $178(57.6 \%)$ \\
\hline CRYO & $40(12.9 \%)$ \\
\hline MIXED & $93(30.1 \%)$ \\
\hline $\begin{array}{r}\text { Table 24: Treatment of patients with incomplete } \\
\text { clearance of genital warts }\end{array}$ \\
\hline
\end{tabular}

$352 / 640(55 \%)$ patients were treated with topical $20 \%$ podophyllin cream and 288/640 patients(45\%) were treated with 5\% topical imiquimod cream (Table 20); 238/352 (67.6\%) patients treated with podophyllin showed complete healing of lesion in comparison to $32.3 \%$ patients treated with $5 \%$ imiquimod showing complete response (Table 21). Table 22 shows time taken for complete healing of lesions with different modalities of treatment. We also attempted to interview every patient by telephone to find out if they had any clinical recurrences for which treatment was sought elsewhere (Table 23).

Overall recurrence was seen in $36.3 \%$ patients.

\begin{tabular}{|c|c|c|c|c|}
\hline Drugs & Cured & Uncured & Total & Cure Rate \\
\hline Imiquimod & 93 & 195 & 288 & $32.3 \%$ \\
\hline Podophyllin & 238 & 114 & 352 & $67.65 \%$ \\
\hline Total & 331 & 309 & 640 & - \\
\hline \multicolumn{5}{|c|}{ Table 25: Statistical analysis of results } \\
\hline
\end{tabular}

Statistical analysis of results was done (Table 25). On applying Fisher test to the results $p$ value comes out to be 0.005 , which is $<0.05$. Hence, the difference obtained was statistically significant and podophyllin $20 \%$ is better treatment of genital warts than imiquimod $5 \%$.

\section{DISCUSSION}

Although non-life threatening, even low-risk HPV-type infections such as anogenital warts carry a substantial psychosocial and economic burden. Stressors include the shame and embarrassment related to diagnosis as well as the inconvenience and discomfort of treatment and the fear of recurrence and transmission.

The literature suggests that anogenital warts are widespread and the prevalence depends on study methodology and higher rates may be reported from passive surveillance of patients. Results presented in this study are from treatment based surveillance at the referral centre and offer a first insight into HPV prevalence in a sample of population from Eastern UP that has not been previously considered and render these findings useful for further investigation in population-based studies from Eastern Uttar Pradesh to further elucidate the epidemiology of this disease in the respective population.

The association with other sexually transmitted diseases in $20.1 \%$ of cases is characteristic and underlines the importance of adequate screening. The retrospective nature of this study makes it difficult to obtain accurate information regarding the incubation period of warts.

The treatment of warts continues to be problematical. In my study podophyllin (20\%) proved to be a much better treatment modality than imiquimod (5\%) for the treatment of genital warts. As of yet there is little evidence to suggest that a single therapy can prove as the gold standard for treatment. We achieved complete remission in only $51.7 \%$ patients with the best possible treatment options available presently. Recurrence was observed in $36.3 \%$ patients, which is too high a variable. Current treatment options focus predominantly on removal of the external wart rather than attacking the underlying viral infection and have thus proven somewhat inadequate in achieving effective long-term results.

In the data reported by the general practitioners and in the data reported by the hospitals at national level, the cases of anogenital warts are seen more frequent in females. In contradiction, in our study from the Dermato-venereological Department at the tertiary centre, there was a majority of males. It is possible that the females with HPV infection have a bigger addressability to gynaecologists and also that they have asymptomatic infection. The HPV infection seems to be more frequent in the rural areas, but this situation is created by the unsafe sexual habits in these areas and perhaps lack of awareness among people in these areas.

Perhaps the low prevalence of infection seen through our study is also demonstrating the low frequency of patients with anogenital warts presenting for dermato-venereological consult. The untreated patients are at risk to develop complications and also are responsible for the spread of the infection. These cases represent a public health concern and HPV medical information (e.g. leaflets for patients, internet announcements) must be spread in the general population.

A reliable electronic system for reporting the HPV cases would permit also contact notification and would decrease the total number of infected persons.

The general costs involved in the management of HPV patients is high due to: (i) the recurrence of the disease, (ii) its complications (e.g. cervical cancer), (iii) asymptomatic viral shedding and (iv) increasing number of new cases.

The logical step to reduce these costs is to increase the awareness of the public on this disease. Our study proved that in the case of HPV infected patients, there is a big discrepancy between data collected by dermato-venereologists in tertiary referral unit in the Eastern UP area and the national data 
records. Those reports need to use the same coding system. An improved electronic system for medical data collection may bring to light the real situation and would permit the identification of needed steps to reduce the incidence of the HPV infection and its comorbidities in the respective area. The high incidence of HPV infection in young persons living in rural areas, revealed by our study, supports the importance of awareness messages that must be transmitted with high priority to this group: firstly, the risk they have by engaging unprotected intercourse and secondly the benefits of the vaccination for both girls and boys.

\section{REFERENCES}

1. Gross G, Pfister H. Role of human papillomavirus in penile cancer, penile intraepithelial squamous cell neoplasias and in genital warts. Med Microbiol Immunol (Berl) 2004;193:35-44. doi: 10.1007/s00430-003-0181-2. [PubMed] [Cross Ref]

2. Insinga RP, Dasbach EJ, Myers ER. The health and economic burden of genital warts in a set of private health plans in the United States. Clin Infect Dis. 2003;36:1397-1403. doi: 10.1086/375074. [PubMed] [Cross Ref]

3. Castellsague X, Ghaffari A, Daniel RW, et al. Prevalence of penile human papillomavirus DNA in husbands of women with and without cervical neoplasia: a study in Spain and Colombia. J Infect Dis. 1997;176:353-361. doi: 10.1086/514052. [PubMed] [Cross Ref]

4. Tay EH, Garland S, Tang G, et al. Clinical trial experience with prophylactic HPV 6/11/16/18 VLP vaccine in young women from the Asia-Pacific region. Int J Gynaecol Obstet. 2008;102:275-283. doi: 10.1016/j.ijgo.2008.03.021. [PubMed] [Cross Ref]

5. Giuliano AR, Tortolero-Luna G, Ferrer E, et al. Epidemiology of human papillomavirus infection in men, cancers other than cervical and benign conditions. Vaccine. 2008;26(Suppl 10):K17-K28. [PMC free article] [PubMed]

6. Lacey CJ, Lowndes CM, Shah KV. Chapter 4: Burden and management of non-cancerous HPV-related conditions: HPV-6/11 disease. Vaccine. 2006;24(Suppl 3):35-41. [PubMed]

7. Arima Y, Winer RL, Feng Q et al. Development of genital warts after incident detection of human papillomavirus infection in young men. J Infect Dis. 2010;202:1181-1184. doi: 10.1086/656368. [PubMed] [Cross Ref]

8. Anic GM, Lee JH, Stockwell $\mathrm{H}$, et al. Incidence and human papillomavirus (HPV) type distribution of genital warts in a multinational cohort of men: The HPV in men study. J Infect Dis. 2011;204:1886-1892. doi: 10.1093/infdis/jir652. [PMC free article][PubMed] [Cross Ref]

9. Garland SM, Steben M, Sings HL, et al. Natural history of genital warts: analysis of the placebo arm of 2 randomized phase III trials of a quadrivalent human papillomavirus (Types 6, 11, 16 and 18) vaccine. J Infect Dis. 2009;199:805-814. doi: 10.1086/597071. [PubMed] [Cross Ref]
10. Graziottin A, Serafini A. HPV infection in women: psychosexual impact of genital warts and intraepithelial lesions. J Sex Med. 2009;6:633-645. doi: 10.1111/j.17436109.2008.01151.x. [PubMed] [Cross Ref]

11. Maw RD, Reitano M, Roy M. An international survey of patients with genital warts: perceptions regarding treatment and impact on lifestyle. Int J STD AIDS. 1998;9:571-578. doi: 10.1258/0956462981921143. [PubMed] [Cross Ref]

12. Tzellos TG, Sardeli C, Lallas A, et al. Efficacy, safety and tolerability of green tea catechins in the treatment of external anogenital warts: a systematic review and metaanalysis. J Eur Acad Dermatol Venereol. 2011;25:345-353. doi: 10.1111/j.1468-3083.2010.03796.x. [PubMed] [Cross Ref]

13. Kodner CM, Nasraty S. Management of genital warts. Am Fam Physician. 2004;70:2335-2342. [PubMed]

14. Brodell LA, Mercurio MG, Brodell RT. The diagnosis and treatment of human papillomavirus-mediated genital lesions. Cutis. 2007;79:5-10. [PubMed]

15. Von Krogh G, Lacey CJ, Gross G, et al. European guideline for the management of anogenital warts. Int J STD AIDS. 2001;12(Suppl 3):40-47. [PubMed]

16. Scheinfeld N, Lehman DS. An evidence-based review of medical and surgical treatments of genital warts. Dermatol Online J. 2006;12:5. [PubMed]

17. Centers for Disease Control and Prevention. Sexually Transmitted Diseases Treatment Guidelines. MMWR. 2006;55(No. RR-11):62-67.

18. Wiley DJ, Douglas J, Beutner K, et al. External genital warts: diagnosis, treatment and prevention. Clin Infect Dis. 2002;35(Suppl 2):S210-S224. [PubMed]

19. Giuliano AR, Palefsky JM, Goldstone S, et al. Efficacy of quadrivalent HPV vaccine against HPV infection and disease in males. N Engl J Med. 2011;364:401-411. doi: 10.1056/NEJMoa0909537. [PMC free article] [PubMed] [Cross Ref]

20. Munoz N, Kjaer SK, Sigurdsson K, et al. Impact of human papillomavirus (HPV)-6/11/16/18 vaccine on all HPVassociated genital diseases in young women. J Natl Cancer Inst. 2010;102:325-339. doi: 10.1093/jnci/djp534. [PubMed] [Cross Ref]

21. Johnston A, Fernando D, MacBride-Stewart G. Sexually transmitted infections in New Zealand in 2003. N Z Med J. 2005;118:U1347. [PubMed]

22. Fairley CK, Donovan B. What can surveillance of genital warts tell us? Sex Health. 2010;7:325-327. doi: 10.1071/SH09145. [PubMed] [Cross Ref] 